\title{
Fostering commercialization of innovation and student entrepreneurship in innovation ecosystems: the case of the Business Center of North Savo in Finland
}

Favorecer la comercialización de la innovación y el emprendedurismo estudiantil
en los sistemas de innovación: el caso del Centro de Negocio de Savo Norte en Finlandia

DOI: $10.22458 /$ rna.v12i1.3556

Jarkko Pellikka Ph.D. ${ }^{1}$

Joonas Ruuskanen Master. ${ }^{1}$

Paola Rosales Suazo de Kontro Master. ${ }^{1}$

${ }^{1}$ Savonia University of Applied Science, Kuopio, Finlandia;

jarkko.pellikka@nokia.com, https://orcid.org/0000-0002-9608-1284; joonas.ruuskanen@uef.fi,

https://orcid.org/0000-0001-6930-5150; paola.kontro@savonia.fi, https://orcid.org/0000-0003-1068-7531

\section{ABSTRACT}

The capability to plan and execute commercialization processes of innovation is crucial for entrepreneurs, SMEs and large companies in a dynamic business environment. Enterprising students particularly need Innovation Support Services (ISS) that focus on their needs, type of service and quality of delivery. Using the case study methodology, this research presents the initiative of the Business Center of the North Savo Program in Finland. Results indicate that entrepreneurs and small firms typically conduct similar steps and, therefore, it is essential to create a comprehensive blueprint of innovation services based on the needs and tailored to the respective phase of commercialization processes.

\section{RESUMEN}

La capacidad de planear y ejecutar los procesos de comercialización de innovación es crucial para los emprendedores, PYMES y las grandes empresas en un entorno empresarial dinámico. Los estudiantes emprendedores en particular necesitan Servicios de Apoyos de Innovación (SAI) orientados en sus necesidades, tipo de servicio y calidad de entrega. Al utilizar la metodología de estudio de caso, esta investigación presenta la iniciativa del Centro de Negocios del Programa de Savo Norte en Finlandia. Los resultados indican que típicamente los empresarios y las pequeñas empresas realizan etapas similares y por lo tanto es esencial crear un programa comprensivo de los servicios de innovación basado en las necesidades y adaptado a la fase respectiva del proceso de comercialización.

\section{RÉSUMÉ}

La capacité de planifier et d'exécuter les processus de commercialisation d'innovation est cruciale pour les entrepreneurs, les PME, et les grandes entreprises dans un environnement commercial dynamique. Les étudiants entreprenants en particulier ont besoin de Services de Soutien d'Innovation (SAI) centrés sur leurs nécessités, type de service et qualité de livraison. En utilisant la méthodologie d'étude de cas, cette recherche présente l'initiative du Centre d'Affaires du Programme de Savo Nord en Finlande. Les résultats indiquent que typiquement les entrepreneurs et petites sociétés réalisent des étapes similaires et c'est pourquoi il est essentiel de créer un programme complet des services d'innovation basé sur les besoins et adapté à la phase respective du processus de commercialisation.

\section{RESUMO}

A capacidade de planejar e executar processos de comercialização de inovação é crucial para empreendedores, PMEs e as grandes empresas em um ambiente empresarial dinâmico. Os estudantes empreendedores, em particular, precisam de Serviços de Apoio à Inovação (SAI) voltados para suas necessidades, tipo de serviço e qualidade de entrega. Quando é utilizada a metodologia de estudo de caso, esta investigação apresenta a iniciativa do Centro de Negócios do Programa Savo Norte na Finlândia. Os resultados indicam que normalmente os empreendedores e as pequenas empresas realizam etapas semelhantes e, por isso, é essencial criar um programa abrangente de serviços de inovação baseado nas necessidades e adequado à respetiva fase do processo de comercialização.

\section{KEYWORDS:}

COMMERCIALIZATION

PROCESS, INNOVATION

SUPPORT SERVICES,

STUDENT

ENTREPRENEURSHIP,

FINLAND.
PALABRAS CLAVE:

PROCESO DE

COMERCIALIZACIÓN,

SERVICIOS DE SOPORTE

DE INNOVACIÓN,

EMPRENDEDURISMO

ESTUDIANTIL, FINLANDIA.
MOTS-CLES:

PROCESSUS DE

COMMERCIALISATION,

SERVICES DE SOUTIEN

D'INNOVATION,

ENTREPRENARIAT

ETUDIANT, FINLANDE.
PALAVRAS-CHAVE:

PROCESSO DE

COMERCIALIZAÇÃO,

SERVIÇOS DE SUPORTE

À INOVAÇÃO,

EMPREENDEDORISMO

ESTUDANTIL, FINLÂNDIA. 


\section{INTRODUCTION}

Globalisation, technological developments and rapidly changing customer requirements have increased the significance of small firms due to their ability to create and exploit innovation. In this context, entrepreneurs play a crucial role in the creation and exploitation of innovations to make the favourable impact on economy. Consequently, educational institutes, researchers and policy-makers have made increasing efforts to identify ways to foster commercialization of innovation and promote entrepreneurship in modern, dynamic business environments in order to promote economic growth. A process that is recognized as playing a key in this context, particularly in rapidly moving, high-technology sectors, is commercialisation (see Pellikka, 2014). However, a number of important aspects of commercialisation have not yet been subjected to empirical analysis, including: the support services involved; and ways in which the commercialisation process can be developed in the innovation ecosystem by the regional organizations. Due to these reasons, the main objectives of this paper are to:

- To describe how commercialization of innovation has been developed in the innovation ecosystem via student entrepreneurship across multiple educational institutes in the North Savo Region in Finland, focusing in the achieved results of the Business Center North Savo

- To show the results of the support activities and the implications for the policy-makers, business developers and educational institutes

Section 2 reviews previous literature regarding commercialization process of innovation studies and the innovation support services. Section 3 introduces the research methodology. In Section 4, the research data of the conducted case study and the results of analysis are presented. Finally, this paper provides concluding notes and implications as well as propositions for further studies.

\section{The Business Center North Savo in Finland}

The Center was created in 2018 as an innovative network aiming at developing entrepreneurship and businesses in North Savo region in Finland on a wide scale. The main objective is to boost business activities by offering entrepreneurship education and training together with services that generate growth, innovation and networking.

The Center provides services for a wide group of actors from inventor to corporate teams, projects, organisations and different research and development communities. The focus is to help start, develop business, and commercialise innovations. The services which are in constantly development include the followings:

- Individual sparring to boost innovation,

- Inspirational and communal events such as Havuja\#!@\%\&! Campfires

- Innovation clinic that provides information on diverse topics such as idea protection, funding, and systematic development of idea.

- Idea workshop, which focus on shaping up a certain business feature, generating new business or alternative way of approaching an existing challenges

-Idea and start up accelerator program called Havuja\#!@\%\&! Program (described later in the article)

-Common entrepreneurial learning environment

-Entrepreneurial education

-Draft Program, a competition of business idea.

\section{Commercialization process of Innovation - literature review}

Previous studies have shown that realising the potential benefits of innovation requires an effective commercialisation process. In this paper, the term 'commercialisation' is perceived as the process of turning ideas into market-competent products, services or solutions in order to create economical value via new business opportunity development (Virtanen and Pellikka, 2018). While 'innovation' is understood as a change to a company's products (either radical or incremental), e.g. a creative improvement of a current product or an idea for a new product, service or solution that might solve specific problems for existing or potential clients if successfully commercialised (Virtanen and Pellikka, 2018; Pellikka, 2014; Jolly, 1997; Andrew and Sirkin, 2003; Pellikka, and Ali-Vehmas, 2019). In this 
respect, innovation is also viewed as a commercial activity, rather than simply a technological process. However, it is important to note that researchers from different disciplines (e.g. economics and technology management) define the term 'innovation' differently and have different approaches to its impact on an industry or a firm's performance and growth (Gopalakrishnan and Damanpour, 1997).

Developing effective commercialisation processes is a complex, challenging task for entrepreneurs, SMEs and large companies in the modern business environment, in which customer requirements are rapidly changing and the lifecycles of new products are shortening. This is especially significant in high technology branches since technologies are changing so rapidly that small firms specialising in the production of high-technology products must match or exceed the pace of change in order to improve competitiveness. Partly for these reasons, small technology firms are increasingly using external competencies and knowledge, accessed via innovation-related networking, in order to accelerate commercialisation, and to reduce associated risks and costs (Chesbrough, 2003; Slowinsky, Hummel, Gupta, and Gilmont, 2009).

Further, as shown by empirical data presented by Feldman (1994), regional contributions to product innovation are related to the underlying inter-organisational relationships, technological infrastructure and availability of relevant knowledge inputs, all of which are mutually reinforcing determinants of a region's competitive advantage. These factors are especially important for small firms, which may be more deeply embedded in regional innovation systems than large corporations are, and thus more dependent on the regional innovation infrastructure and social networks (Galbraith et al., 2008).

It has been argued that the local service infrastructure should provide a nurturing environment for high technology firms to support and accelerate the innovation activities of small technology firms and, thus, enhance regional economic growth. In addition, it has been recommended that priority should be given to policies designed to promote technology development and technology-based business by (for instance) establishing business centers, science parks and business incubators (Abetti and Rancourt, 2006). Accordingly, major objectives of economic policies have been to provide suitable infrastructure and enhance the availability of appropriate innovation support services for small technology firms. However, it has been argued that studies should be more focused on identifying effective instruments and their integration within a wider support system and the optimal deployment of public policy to promote entrepreneurship and innovation. Thus, there is a need to examine the requirements e.g. of student entrepreneurs and small firms associated with the commercialisation process and to identify potential alternatives to help these firms to overcome the challenges associated with the process.

In addition, it has been seen that innovation support service providers should focus more on the content and increase needs orientation of the process of delivering services (Heydebreck et al., 2000). This also requires further understanding of execution, stages and key challenges of the process. Thus, the Innovation Support Services (ISS) should better response to the real needs of the student entrepreneurs and small firms that are influenced by the educational level, personal motivation, technology intensiveness and market conditions. Previous studies have reported that several ISS have failed to fulfil these objectives (Pellikka and Virtanen, 2009). Therefore, much more can be done in order to use the existing framework of commercialization process as a basis and further link the services to that as part of the wider entrepreneurship education initiative.

\section{RESEARCH METHOD AND DATA}

When examining the commercialization process in this type of research context, concepts and information from a large range of disciplines, such as business economics, organisation theory, industrial relations and innovation management studies need to be taken into account. Previous authors have reported that case study analyses can potentially improve the relevance of management and innovation studies among small technology firms (Spence, 2003). In addition, as noted by Eisenhardt and Graebner (2007), case studies can provide valuable insights into innovation, particularly from organisational, sociological and managerial perspectives. Therefore, a qualitative approach based on the case study method was adopted, which enabled us to study commercialization and the student entrepreneurship in their natural settings in an attempt to interpret the phenomena of interest and to gain a holistic overview of the context (Miles and Huberman, 1994). The following chapter provide a description of the case of this study. 


\section{Case description - Developing Commercialization of Innovation and Student Entrepreneurship in Business Center North Savo Program}

Entrepreneurship offers not only a path for young people to transform their own lives, but also a way to empower others as pointed out by the United Nations Sustainable Development Goals (SDGs). Therefore, young and student entrepreneurs need the specific entrepreneurship education and training programs especially on commercialization of innovation, to both foster development and drive regional economic growth, job creation and new businesses via innovation. However, the education system in EU countries is not currently flexible enough to provide learning opportunities for the students including programs for the students to accelerate the growth of new ideas (Kaufmann and Tödtling, 2002). Another challenge is that a fragmented support infrastructure to effective promote entrepreneurship (e.g. entrepreneurship education and training) is unable to optimal create an encouraging environment for learning and education from the primary schools to higher education institutes (HEIs).

In order to respond these challenges Business Center North Savo Program was initiated in 2018. In order to ensure sustainable regional economic growth in the sparsely populated North Savo region, located in the Eastern Finland, one main goal has been to drive a knowledge-based joint entrepreneurial learning environment. This is particularly essential since the per capita GDPs of the regions of Eastern Finland are below both OECD and national average.

Business Center North Savo Program has been building up and continuously improving a joint entrepreneurial learning environment combined with the commercialization process of innovation to cover all three education levels. The Business Center North Savo development work is coordinated by Savonia UAS together with its partners Savo Vocational College Sakky, City of Kuopio, Navitas Business Services in Varkaus, University of Eastern Finland and City of Iisalmi and Ylä-Savo Vocational College YSAO. Business Center program receives project funding from the ELY Center of South Savo (ESR) and the Regional Council of North Savo (EAKR). Total budget of the program is EUR 2,2M€ during 2018-2021.

\section{Entrepreneurship Learning Environment to Accelerate Commercialization Process of Innovation Results, Unique Features and Implications of the Program}

The Business Center North Savo Program has created one common entrepreneurship learning environment with the program educational partners for over 30.000 students in the region. This learning environment provides a diverse entity on entrepreneurship education and training opportunities available for the students at the all three educational levels. One objective has been to enhance a positive attitude towards starting new businesses, which has meant the practical development of knowledge and skills and the growth of student-driven entrepreneurship among the main educational institutes and the innovation ecosystem partners of the region.

In addition, many conducted key initiatives have accelerated the creation of the entrepreneurship culture and community via a large number of student entrepreneurship events, trainings, workshops and hackathons to inspire and encourage the new business journey. It has been essential that students can start and develop their required competences and capabilities flexible and in an agile way as part of their standard study programs. Business Center team has been able to customize the productized offering based on the received requirements, feedback and the educational level of the students.

The productized offering of Business Center can be divided into four stages:

1. Inspiration and interest toward innovations and entrepreneurship,

2. Inventing and developing new business ideas,

3. Conception and testing solutions, and

4. Establishing and having a growth capable company.

At the first stage, communal and inspirational events, such as Havuja\#!@\%\&! Campfires, provide a basis for interest toward innovations and entrepreneurship. In these events, various themes of innovations and entrepreneurship are dealt with quest speakers and joint discussions. The second stage is where people with different skills and knowledge are brought together to invent new ideas. Potential customer needs and megatrends are important part of inventing 
business ideas at this stage. Ideation workshops and innovation projects are tools to create an opportunity for ideation and first development activities. After ideation and finding out what ideas are interesting, the participant should start the third stage. In this stage, a facilitator or a team develops the idea further by verifying customer needs and market potential and obtaining information and skills to move forward. These activities together with planning and pitching trainings forms Havuja\#!@\%\&! Bootcamp Idea Accelerator program. Pilots and customer tests are part of this stage. The fourth and final stage occurs when a new growing company is about to establish or it is just established. Havuja\#!@\%\&! Accelerator program for startups increases participant's knowledge about entrepreneurship and provides new networks to contact investors, collaborators and specific service providers. These activities enhance the opportunities of a company to succeed and grow. During all the four stages, individual sparring sessions are also organized, although communal learning and collaboration are highlighted in the context of the Business Center. See Appendix 1. Business Center Environment.

Business Center continuously improve all the productized services based on the student and/or customer feedback. The feedback has been collected during each program as well as after the program in order to utilize the received information effectively for the further improvement purposes'. This has ensured a student-based experience and approach (i.e. entrepreneurship learning environment) that enables all students to use seamlessly available entrepreneurship training, accelerator and other development services across the educational levels and across regional innovation ecosystems. In addition, the entrepreneurial environment provides individual small group learning opportunities, peer support, informal information exchange and individual counselling for the students that are motivated to start and accelerate their entrepreneurship-related efforts. With this types of supports, the entrepreneurship education, training and coaching also better considers the different requirements (e.g. personal interests on entrepreneurship, educational level and other motivational aspects) especially among the young people and the students, as also pointed out by the Finnish Government and Confederation of Finnish Industries (EK).

This entity has been implemented with a large number $(20+)$ of collaborators including the following regional, national and international organizations: City of Kuopio, City of Varkaus, City of Iisalmi, The Regional Council of Pohjois-Savo, Karelia UAS, Riveria Vocational College, Federation of Finnish Enterprises, Global Entrepreneurship Program, The Young Entrepreneurship Association, Finnish Business Angels Network, The Institute for Small Business and Entrepreneurship (ISBE), and The International Society for Professional Innovation Management (ISPIM). This collaboration also involves a numerous of startups, SMEs, large companies and municipalities located especially in the North Savo. As the results show, the Business Center Program has made entrepreneurship and innovation education more visible at the all educational levels from primary schools to university students. This has enabled unique entrepreneurship learning opportunities from the fundamental level to highly advanced level including a balanced entity of practices and theory.

The concrete results on the entrepreneurship learning environment have been summarized in the table below (Table 1.)

\section{Table 1}

Participant of the Entrepreneurship Learning Environment between 2018 and 2020

\begin{tabular}{|c|c|c|c|}
\hline Result category & 2018 & 2019 & $\begin{array}{l}2020 \\
\text { (Cumutative) }\end{array}$ \\
\hline $\begin{array}{l}\text { Number of students contacted related to the } \\
\text { entrepreneurship learning and training opportunities }\end{array}$ & 6200 & 15100 & 32650 \\
\hline $\begin{array}{l}\text { Number of students in the joint entrepreneurship } \\
\text { learning environment }\end{array}$ & 80 & 750 & 1060 \\
\hline $\begin{array}{l}\text { Number of the entrepreneurship training, coaching } \\
\text { and workshop sessions arranged with the students }\end{array}$ & 34 & 138 & 264 \\
\hline $\begin{array}{l}\text { Number of the events for students arranged } \\
\text { to promote entrepreneurship and common } \\
\text { entrepreneurship learning environment }\end{array}$ & 5 & 84 & 141 \\
\hline Number of new student-based companies established & - & 8 & 16 \\
\hline $\begin{array}{l}\text { Number of presentations on the entrepreneurial } \\
\text { learning environment for the international visitors and } \\
\text { international student groups }\end{array}$ & 2 & 18 & 27 \\
\hline
\end{tabular}

Source: authors. 


\section{RESULTS AND IMPLICATIONS}

Business Center program has created and successfully implemented a novel learning environment on entrepreneurship targeted particularly for the students to promote a culture open to the expansion of new ideas and visions overcoming regional expectations. At the general level, this learning environment has been anchored into a key regional, national and international initiative to accelerate regional economic growth and profited-oriented transformation.

The unique elements of the entrepreneurship learning environment to promote commercialization process of innovation can be summarized as follows:

Entrepreneurship learning environment has created and continuously improved the horizontal entrepreneurial ecosystem and the essential building blocks for the regional vertical ecosystems (e.g. for nationally recognized energy and smart water ecosystem). In practice, this means that direct activities (e.g. entrepreneurial training, education and coaching) to enhance entrepreneurship competences enable formation of new companies and growth of the existing companies in the vertical ecosystems (i.e. absorptive capacity between the ecosystems). In addition, we have created and deployed cross-ecosystem linkages that play a key role, not only during the opportunity recognition, formation and startup phase, but also during the later phases on commercialization and growth. To sum up, the entrepreneurship learning environment has systematically built horizontal capabilities across all vertical ecosystems enabling accelerated growth of entrepreneurship in each regional ecosystem.

Easy (one-stop) and flexible access into all entrepreneurship studies, training, coaching and innovation services for all students at the three educational levels (i.e. education-level agnostic approach). As pointed out earlier, one main challenge of the entrepreneurship services is fragmentation. Based on this, and the collected feedback and requirements from the student and entrepreneurship society, as well as the funding organizations, Business Center North Savo program has taken this centralized approach to solve this critical element. The importance of the centralized approach has been also underlined as a part of the Finnish government strategic initiatives (2019), and as part of Federation of Finnish Enterprises official announcements (June 3rd 2019).

One common curriculum on entrepreneurship basics for all the students (app. 30.000) in the North Savo region. This provides flexibility and concrete value for the students at the different education level Therefore, a unique offering (total 15 credits) that consists of three main training modules on entrepreneurship, new business opportunity development and commercialization was created and opened for the students. This content is currently in the heart of the entrepreneurship research (Virtanen \& Pellikka, 2018). This common offering provides the most modern approach on entrepreneurship fundamentals for all the students.

Centralized collaboration and communication between the education providers and other organizations on the entrepreneurship learning and training opportunities. Previous studies have shown that the development of the entrepreneurship ecosystems need strategic approach, meaning a systematic and well-articulated plan and execution of the ecosystem activities (Autio et al., 2018; Pellikka and Ali-Vehmas, 2016). In order to effectively respond to this need, all the main activities related to the entrepreneurship learning environment have been managed via centralized team and governance. In addition, this ensured timely and effective communication with the most relevant content on the learning opportunities via the selected communication channels.

Productized, tested and validated entrepreneurship services (e.g. student events, workshops, training events, acceleration program among others) to enhance student preparedness among a large student community in the region including the national and international linkages to other accelerators, startup hubs and entrepreneurship networks and associations. Major proportion of these services are digital-native, and thus can be effectively used in other cities and regions in EU.

Business Center team has created the common IPR processes and practices for all educational levels in collaboration between University of Eastern Finland, Savonia UAS and Savo Vocational College Sakky to accelerate commercialization of student-based innovations. One common and externally communicated IPR practice accelerates especially the establishment of a new enterprise and increases attractiveness of the region in the eyes of the business angels, venture capitalists and other parties that are seeking growth-oriented young and talented businesspersons. 


\section{CONCLUSION}

This research presents the achieved results from the regional business development initiative in Finland, the Business Center North Savo. In addition, this paper presents how these services should be created and delivered in order to enhance the commercialisation process of innovation. This study shows that students, student entrepreneurs and small firms are seeking, particularly, knowledge-based resources from Innovation Support Services (ISS) to accelerate the procedures to development innovation. In addition, companies can leverage their knowledge throughout the organisation, expand their knowledge further based on existing expertise, appropriate knowledge from the other innovation ecosystem partners and other organisations and develop completely new expertise by probing new technologies and/or markets.

In other words, and entrepreneur and the firm plays an integrating role by bringing together diverse inputs and specialised knowledge (Pellikka and Ali-Vehmas, 2016). One very noticeable characteristic related to the resourcebased theory is that knowledge, ideas or valuable resources does not ensure profits. Efficient markets provide profits only to successfully applied ideas. From this perspective, we can see the close relationship that exists between the value of knowledge and the commercialisation process, because the commercialisation is the only way that the company can realise the value of the new knowledge-based idea. 


\section{REFERENCES}

Abetti, P.A. and Rancourt, C.F. (2006). University incubators as agents for technology transfer and economic growth: case studies in USA, Ukraine and Finland. International Journal of Technology Transfer and Commercialisation, $5(4), 307-338$.

Andrew, J.P. and Sirkin, H. (2003). Innovating for Cash. Harward Business Review, September, 76-85.

Autio, E., Nambisan, S., Thomas, L.D. and Wright, M. (2018). Digital affordances, spatial affordances, and the genesis of entrepreneurial ecosystems. Strategic Entrepreneurship Journal, 12(1), 72-95.

Chesbrough, H. (2003). Open Innovation: The New Imperative for Creating and Profiting from Technology. Harvard Business School Press.

Eisenhardt, K., Graebner, M. (2007). Theory Bulding From cases: Opportunities And Challenges. Academy of Management Journal, Vol. 50, feb, No. 1, 25-32.

Feldman, M.P. (1994). The Geography of Innovation. Kluwer.

Galbraith, C.S., Rodriguez, C.L. and DeNoble, A.F. (2008). SME Competitive Strategy and Location Behavior: An Exploratory Study of High-Technology Manufacturing. Journal of Small Business Management, 46(2), 183-202.

Gopalakrishnan, S. and Damanpour, F. (1997). A Review of Innovation Research in Economics, Sociology and technology Management. Omega, International Journal of Management Science, 25(1),15-28.

Heydebreck, P., Klofsten, M. and Maier, J. (2000). Innovation support for new technology-based firms: the Swedish Teknolopol approach. RED Management, 30(1), 1-12.

Jolly, V.K. (1997). Commercialising New Technologies: Getting from Mind to Market. Harward Business School Press.

Kaufmann, A. and Tödtling, F. (2002). How effective is innovation support for SMEs? An analysis of the region of Upper Austria. Technovation, 22(3), 147-159.

Miles, M., Huberman, A. (1994). Qualitative Data Analysis. SAGE Publications.

Pellikka J. and Virtanen M. (2009). The Problems of Commercialization in Small Technology-based Firms. International Journal of Entrepreneurship and Innovation Management, 9(3), 267-284.

Pellikka, J. (2014). The Commercialization Process of Innovation in Small High Technology Firms - Theoretical Review. In F. Therin (ed.), Handbook of Research on Techno-Entrepreneurship. How Technology and Entrepreneurship are Shaping the Development of Industries and Companies (2nd ed.). Edward Elgar Publishing.

Pellikka, J. and Ali-Vehmas, T. (2016). Managing Innovation Ecosystems to Create and Capture Value in ICT Industries. Technology Innovation Management Review, 6(10).

Pellikka, J. and Ali-Vehmas, T. (2019). Fostering Techno-Entrepreneurship in the Innovation Ecosystems - Case Nokia. In F. Thérin, F. P. Appio and H. Yoon (eds.), Handbook of Research on Techno-Entrepreneurship. How Technology and Entrepreneurship are Shaping the Development of Industries and Companies (3rd ed.). Edward Elgar Publishing

Slowinsky, G., Hummel, E., Gupta, A. and Gilmont, E.R. (2009). Effective practices for sourcing innovation. Research Technology Management, 52(1), 27-34.

Spencer, J. (2003). FIRMS' KNOWLEDGE-SHARING STRATEGIES IN THE GLOBAL INNOVATION SYSTEM: EMPIRICAL EVIDENCE FROM THE FLAT PANEL DISPLAY INDUSTRY. Strategic Management Journal, Strat. Mgmt. J., 24: 217-233, DOI: 10.1002/smj.290.

Virtanen, M. and Pellikka, J. (2018). Integrating opportunity development and commercialisation process. International Journal of Business and Globalisation, 20(4), 479-496. 


\section{Appendix 1.}

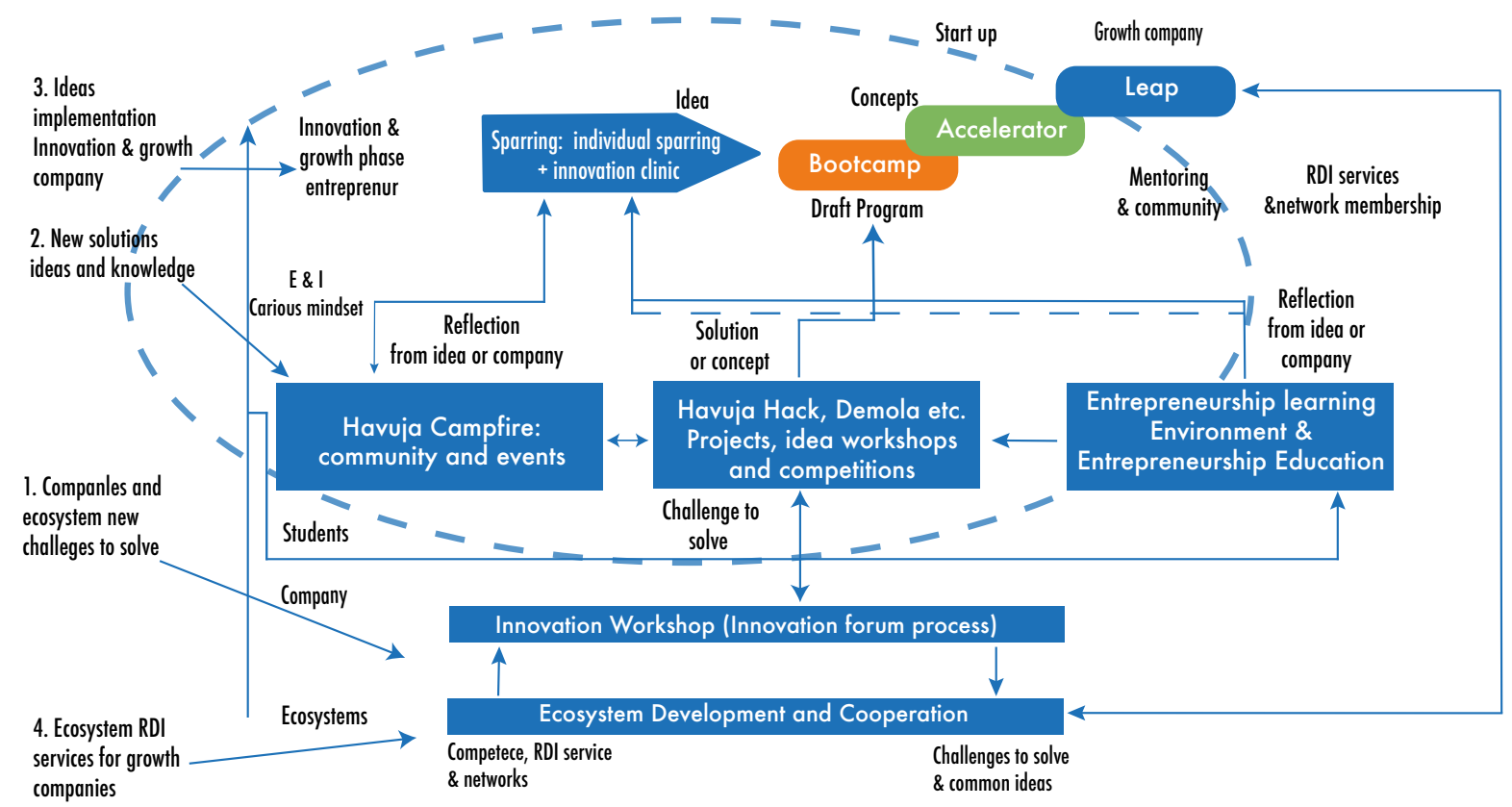

Business Center Environment 